症例

脱出胃に早期癌が併存した Morgagni 孔横隔膜ヘルニアの 1 例

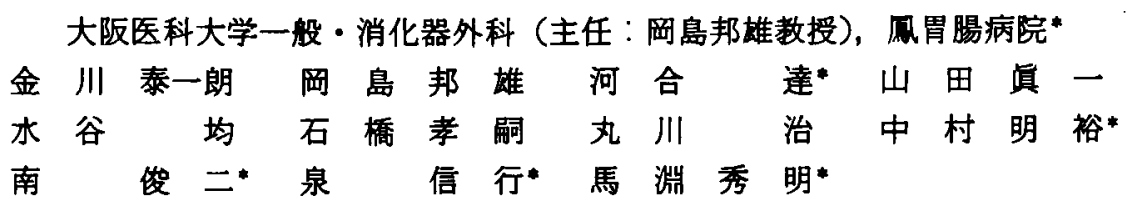

症例は76歳女性，主訴は暒気で，胸・腹部単純 X 線にて右胸腔内と左横隔膜下に踥面 形成を有したガス像を認めた。消化管造影にて胃前庭部と横行結晹が右胸肋三角部より 右胸腔内へ脱出し, Morgagni 孔へルニフと診断した。ささらに胃透視と内視鏡にて幽門部 の陌凹性病変を診断し，低分化腺癌を確診した。 上腹部正中切開にて開腹し，Morgagni

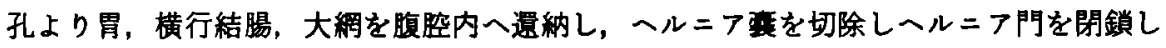
た後，幽門側胃切除術，リンパ節郭清術を行った。本邦において1990年までに報告され 検索しえた Morgagni 孔へルニフの232例（自検例を含む）を集計し報告した，自呀例の

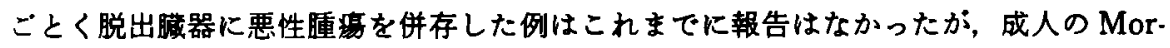
gagni 孔へルニフには，脱出臟器の悪性㾝湯を含めた病変の検索を念頭におく必要があ ると思われた。

索引用語 : Morgagni 孔横隔膜ヘルニア, 早期胃癌

\section{精 䡒}

Morgagni 孔横隔莫ヘルニフは，横隔膜ヘルニフの らち右胸肋三角部 (Morgagni 孔)から腹腔内臓器が胸 腔内人脱出するールニアで，比較的稀な疾患とされて いる. 今回われわれは，胸腔内へ脱出した胃の幽門部 に早期癌を併存したきわめて稀な Morgagni 孔へル ニフの 1 例を経験したので，本邦における1990年まで に検索可能であった231例を集計し，文献的考察を加兄 て報告する。

\section{症例}

症例：76歳，女性.

主訴：喝気。

既往歴：特記することなし.

家族歴：特記することなし。

現病歴：生来健康であった。半年前より食後の嘔気 を覚えるようになったが，食事量をひかえることによ り症状は軽快していた，最近になり腹部膨満感，嘬気 が増強したため来院した。

理学的所見：栄羡状態は良好，可視粘膜に黄庭奢血 なく，右胸部は呼吸音がやや減弱し，上腹部には軽度

1992年11月 9 日受付 1993年 5 月12日採用
の压痛と抵抗を認めた。

血液学的所見：RBC 442 万 $/ \mathrm{mm}^{3}$, WBC $6,800 /$ $\mathrm{mm}^{3}$, Hct $40.7 \%$, Hb $13.4 \mathrm{~g} / \mathrm{dl}$, T.P $8.5 \mathrm{~g} / \mathrm{dl}$, GOT 20u/ml, GPT $17 \mathrm{u} / \mathrm{ml}$, LDH $368 \mathrm{u} / \mathrm{ml}$, T. bil $1.4 \mathrm{mg} /$ $\mathrm{ml}$, BUN $24 \mathrm{mg} / \mathrm{dl}$, Na $151 \mathrm{mEq} / l$, K $3.8 \mathrm{mEq} / l$, Cl $94 \mathrm{mEq} / l$, CEA $1.1 \mathrm{ng} / \mathrm{ml}$.

脢・腹部立位草純 X 緗所見：正面像にて右下肺野に 籍面形成を有した票胞状ガス像と，左横隔膜下に鏡面 形成を有した胃泡と思われるガス像を認めた（Fig. 1).

消化管 X緗所見：経县管を用いたBariumによ る上部消化管造影と注腸の結果，胃前庭部と横行結腸 か，胸骨下部背面の右側より右胸腔内一脱出している のが認められた（Fig. 2).このX線所見よりMorgagni 孔である右胸肋三角部より腹腔内眡器が胸腔内 一脱出した Morgagni 孔へニニアと診断した。脱出に 上る胃の变形は著しく，消化管造影の操作は困難で あったか，幽門部に大きさ約 $2.5 \mathrm{~cm}$ の不整形の陥凹性 病変と陥凹内の島状低隆起を二重造影にて描出し，早 期胃癌（IIC）を強く疑った（Fig. 3).

男内視鏡所見：胃幽門部の大繁側に辺绿に不整な哭 赤を有した陌凹性病変を認め, 早期胃癌, 肉眼型 IIc と 


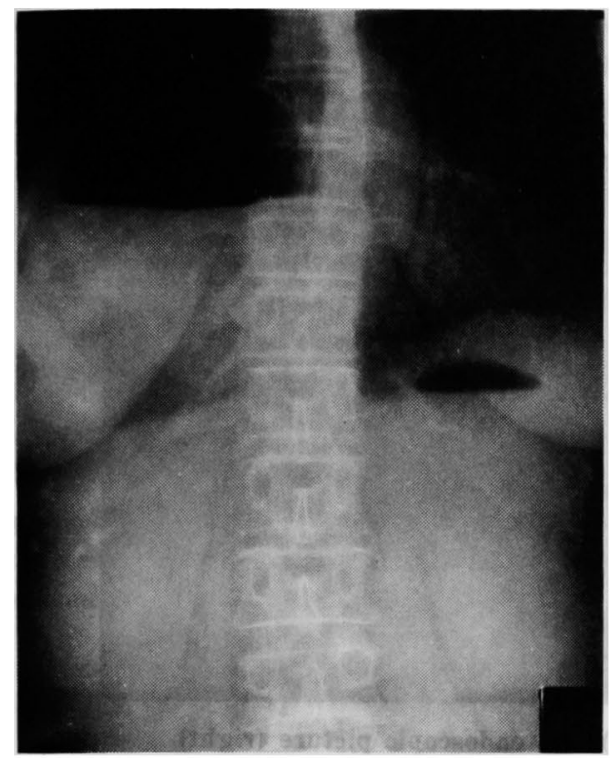

Fig. 1 Abdominal plain X-ray film showed a marked pool of gas and fluid level in the right thoracic cavity and left subphrenic region.

診断した。へルニフによる著明な胃の変形のため内視 鏡の幽門輪通過が不能で，十二指腸は観察しえなかっ
た.胃生検の結果は低分化腺癌と診断された(Fig. 3). 腹部超音波所見：胆衰内に䄪 $3 \mathrm{~mm}$ 大の小結石を数 個認めた。

手術所見：上腹部正中切開にて開腹した，腹水の貯 留はなく，大網，横行結腸，胃前底部が肝左葉の前面 を経て Morgagni 孔より右胸腔内人脱出していた (Fig. 4)。これらを用手的に腹腔内へ還納したが操作 はきわめて容易で，ヘルニフ震と大網は軽度線維性に

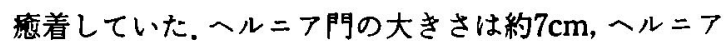
要は直径約 $15 \mathrm{~cm}$ で，ヘルニア萁を切除しへルニア門 を繾合閉鎖した後，胃癌と胆石症に対し幽門側胃切除

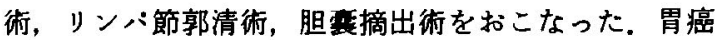
の術中所見は $\mathrm{H}_{0} \mathrm{P}_{0} \mathrm{~S}_{0} \mathrm{~N}_{1}(+)$ Stage II で, Antrum の 大警に大きさ約 $1.5 \times 3.0 \mathrm{~cm}$ の IIc とその周囲に随伴 した大きさ約 $6.5 \times 4.0 \mathrm{~cm}$ の IIbを認めた(Fig. 5).病 理組織学的診断は Poorly differentiated adenocarcinoma, sm, Inf $\beta$, scirrhous, ly $1, \mathrm{v} 0, \mathrm{n} 1(+)$, stage IIであった（Fig. 6）．胆变には黒色石 5 個を認め， chronic cholecystitis $の$ 像を呈していた。

術後経過：患者は著変なく良好に経過し, 術後の注 腸検查にても異常所見はなく，第48病日に軽快退院し た.
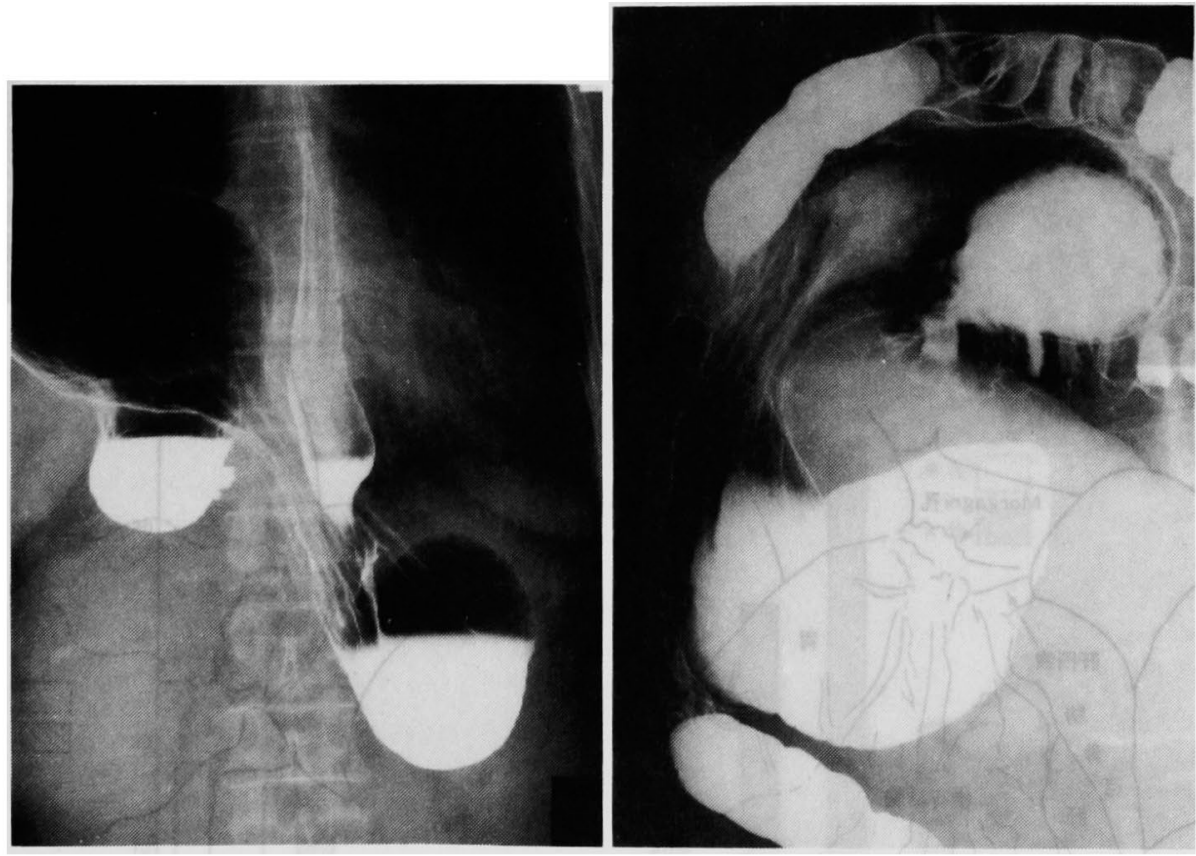

Fig. 2 Gastrointestinal barium study showed the prolapse of the dilatated gastric antrum and transverse colon into the right thoracic cavity via Morgagni's foramen. 

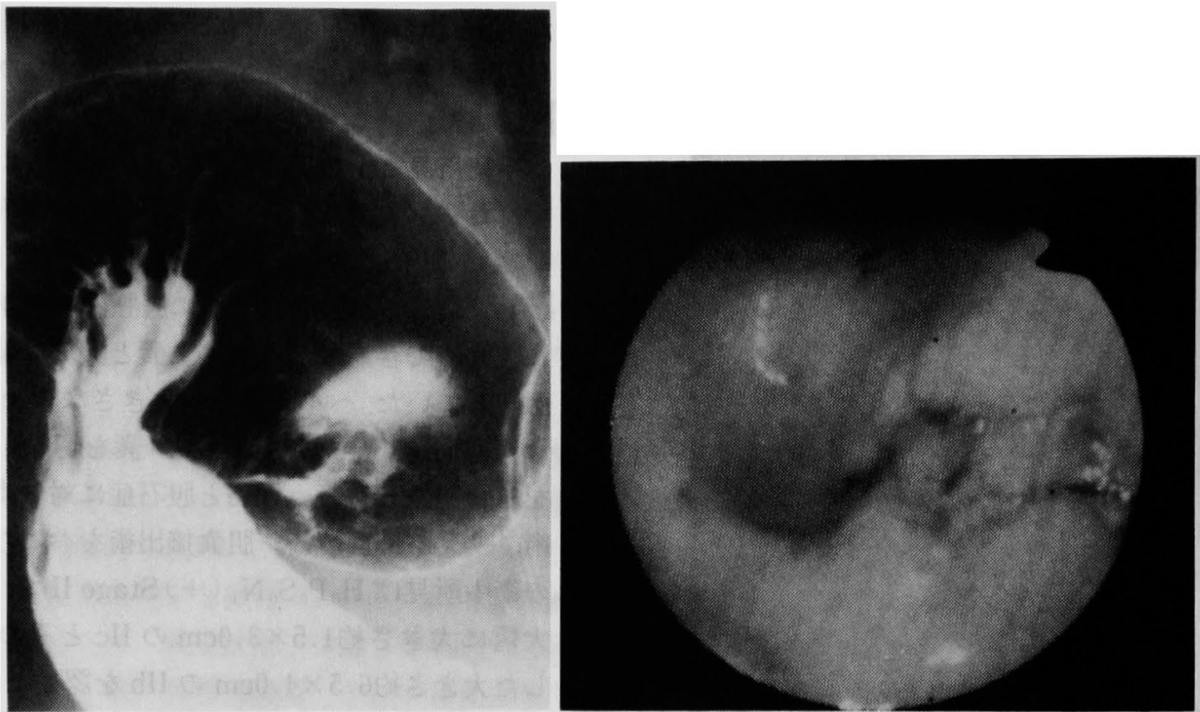

Fig. 3 A double contrast radiography (left) and endoscopic picture (right) showed irreqular-shaped shallow ulceration and some elevated lesions of the pyrolic region.
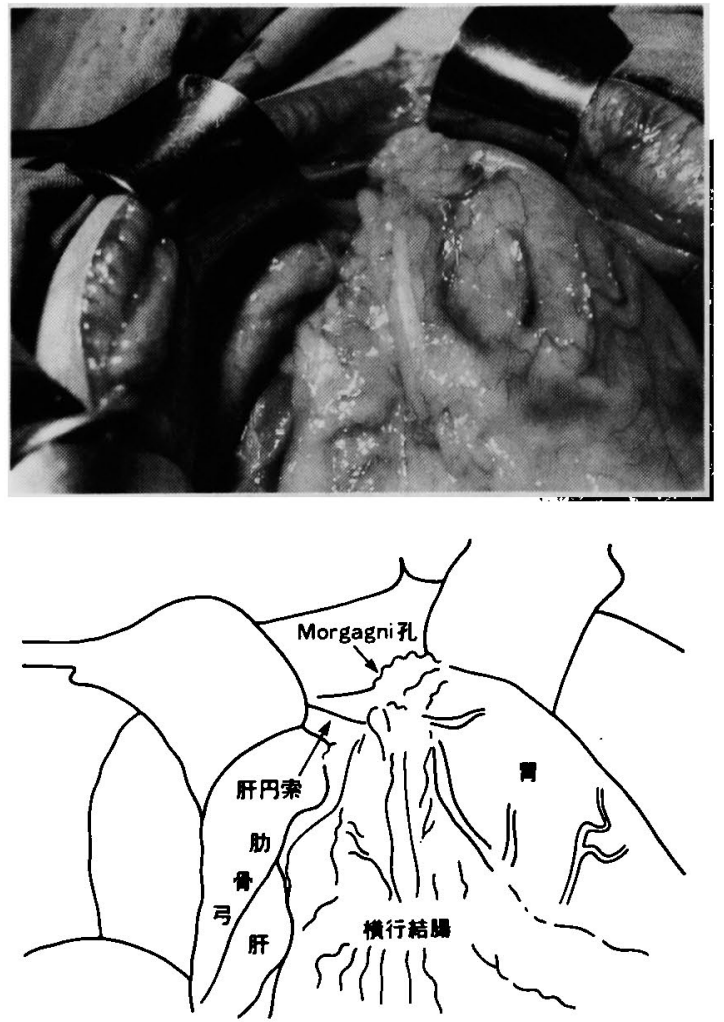

Fig. 4 Intraoperative photography (upper) and its schematic illustration (below).
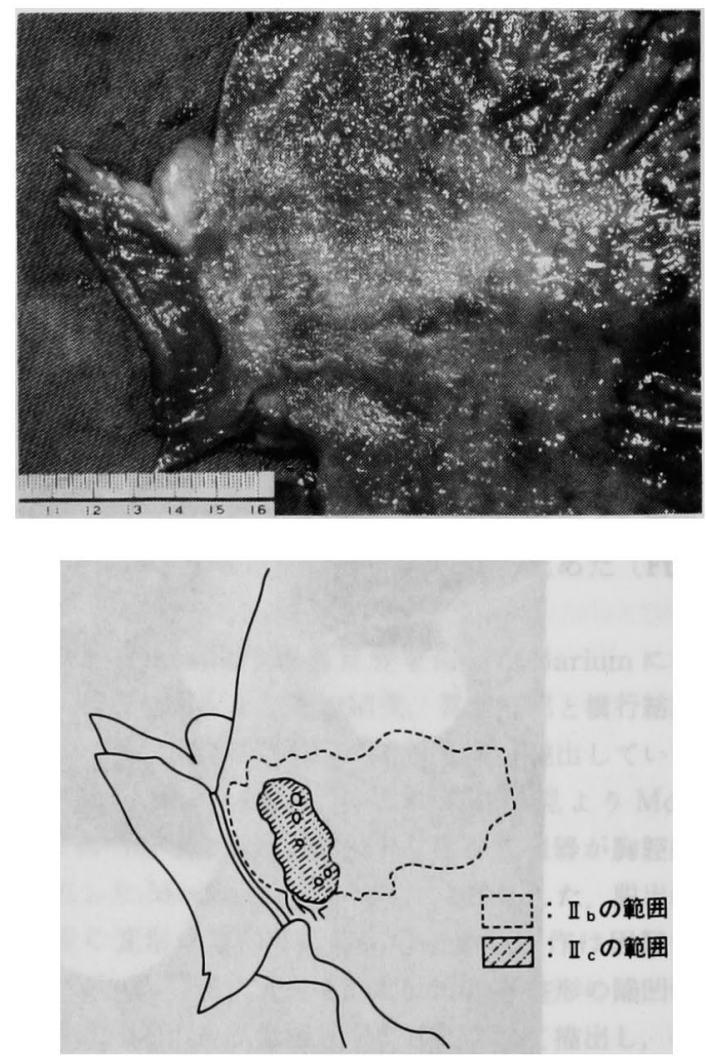

Fig. 5 Macroscopic picture of the resected stomach (upper) and its schematic illustration (below). 


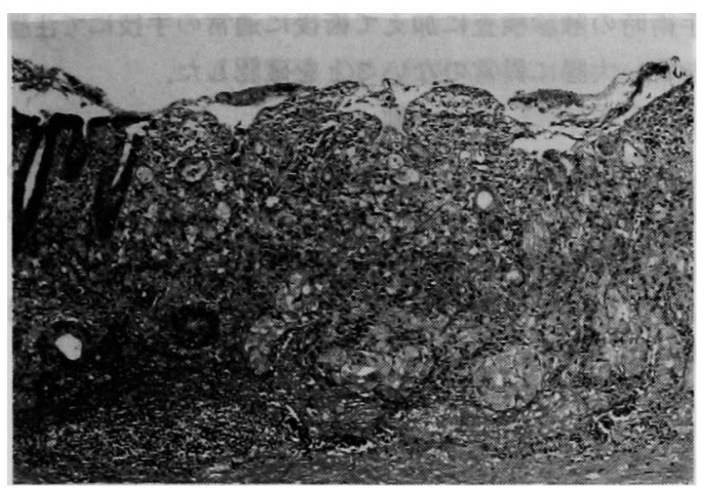

Fig. 6 Histological picture showed poorly differentiated adenocarcinoma of stomach with submucosal invasion (H.E, $\times 200$ ).

\section{考察}

Morgagni 孔横隔膜へルニフは，1761年にMorgagni が剖検による横隔膜前部の欠損を報告したのが 最初で, 胸骨剣状突起後面の横隔膜胸骨部と同肋骨部 との境の朐助三角をールニフ門とする横隔膜へル = である. Comer')の報告によると横隔膜へルニア全体 の約 $3 \%$ の須度で比較的稀な疾患とされている。本邦 では，1926年に飯田 ${ }^{2}$ が剖検例で初めて報告して以来，

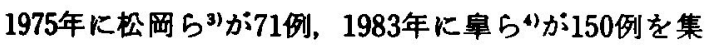
計し報告している．今回われわれの行った1990年まで の文献梌索の結果, 本症の報告は自験例を含めて232例 であった。このらち記載の明らかな報告例について集 計し検討を加えた。
発症年龄，性差：報告された Morgagni 孔へルニフ 全体の平均年龄は 45.1 墄であったか，年齢分布に特徵 があり 10 歳未满と50歳代～70歳代においてて各々全体の 26\%, 57\%を占め二峰性の分布を示していだ)ー6).性差 は男性61例，女性158例，男性：女性=1：2.59で，全 体に女性に多いが, Table 1 のごとく20歳代までは, 男 性がやや多く，30嵗以上では性差は逆転して女性が優 位となり，50歳以上では圧倒的に女性に多く発症する 㑯向があった4)(Table 1)。このような二峰性を示し た原因として, Morgagni 孔へルニアの成因には胎生 期の横隔獏前方部の Septum Transversum の形成不 全が関与した胸肋三角部の横隔膜部筋肉形成不全また は欠損を原因とする先天性の要因と，加龄，肥满，妊 娠などによる腹壁の脆弱化や腹圧の上昇を原因とする 後天性の要因の 2 つが考えられ，若年者ではMorgagni 孔ールニフとともに心奇形等の先天異常を伴 5 顔度が53例中16例 ( $30.2 \%$ ) と高いことより"先天性の 要因が考えられ，成人では中高年の女性に多いことよ り後天性の要因か関与しているからではないかと考え られる.

ヘルニフ内容: Morgagni 孔へルニフのヘルニア内 容として，大網，結腸，肝，小腸，胃，胆麦，十二指 腸，脾践が報告されている，その頻度（重複を含む） は219例中大網129例(58.9\%), 横行結腸114例(52\%), 小腸27例(12.3\%), 肝 24 例(10.9\%), 胃16例(7.3\%), 胆衰 5 例 $(2.2 \%)$ ，十二指腸 4 例 (1.8\%)，脾脸 2 例 (0.9\%) で，大網と横行結腸が大半を占めている。年 龄からみたールニア内容の頻度（重複を含む）の差は,

Table 1 本邦におけろ Morgagni れヘルニアの年粭・男女別分布（219例）

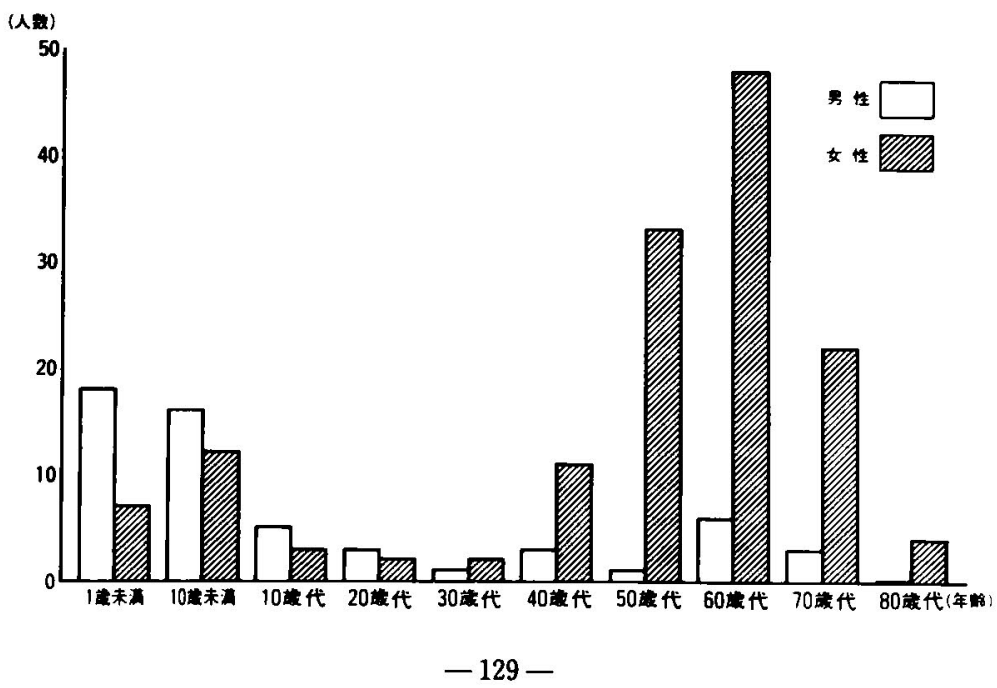


10歳未満では結腸 (46\%), 肝 (18\%), 大網 (14\%), 小腸 $(10 \%)$ ，胃 ( $8 \%)$ ，十二指腸，胆言，脾缄の順 であるのに対して, 10藏以上では圧倒的に大網(52\%)， 結腸 (38\%) が多く，ついで小腸 ( $5 \%$ )，胃 ( $4 \%$ ), 肝 $(3 \%)$ ，胆衰，十二指腸の順であった，小児と成人 のールニフ内容に差が見られるのは, 個々の腹部葴器 の発育の差，大きさの違いによるものと考えられる。

合併症：成人例の合併症についてみると，腸閉塞症 14例, 食道裂孔へル $=>8$ 例, 较扼による穿孔性腹膜 炎 3 例，悪性看瘍 3 例（胃癌 3 例，自験例を含む)，胃 十二指腸漬瘍 2 例，胆石症 2 例(自験例を含む)，小腸 軸念転症 1 例の報告があった. Morgagni 孔へルニフ に悪性腫場を合併していた他の 2 例の報告は，ともに 自験例とおなじ胃癌症例であった。1 例目息は，61歳女 性の幽門部進行胃癌の手術時に大網の一部が右胸腔内 一脱出しているのが偶然発見された例であり，2 例 目9は73歳女性の前庭部胃癌の術前検查時に横行結腸 が右胸腔内へ脱出しているのが認められた例であっ た。この報告された 2 例はともにールニア内容に胃は 含まれておらず，自験例の上5に脱出した胃に早期癌 を認めた例の報告はなく，文苚上検索した限りにおい て本例が第 1 例目でありきわめて稀と考えられた。 た成人でへルニフ内容に胃が含まれていたのは232例 中 9 例 (3.8\%) であったが胃になんらかの病変を指摘 された報告すなかった，自験例のごとき症例の頻度は きわめて低いと思われるが，わが国に胃癌が多いこと を考えると，脱出した胃に対しては悪性渪煬を含めた 病変の検索を念頭におく必要があると思われた。 また Table 1 で示したように癌年龄である中高年の女性に 好発し，約 $40 \%$ の頻度で横行結腸がールニア内容に含 まれることより，近年増加傾向にある大腸癌の合併の 有無の険索む重要ではないかと考えられた。自駼例に おけるールニア内容に含まれた横行結腸に対しては，
手術時の触診検査に加えて術後に通常の手技にて注腸 を行い大腸に異常のないことを確認した。

桔語

胸腔内へ脱出した胃の幽門部に早期癌を認めたきわ めて稀な Morgagni 孔ールニフのI例を释験したの で，文献的考察を加えて報告した。

本文の要旨は第48回日本臨床外科医学会総会において器 表した。

\section{文献}

1) Comer TP, Clagett $O T$ : Surgical treatment of hernia of the foramen of Morgagni. J Thorac Cardiovasc Surg 52: 461-468, 1966

2）板田四郎：初生児横隔膜「ヘルニフ」の1例。坚科 雑誌 $317: 1570,1926$

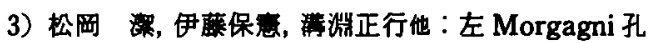
ヘルニフの1例と本邦報告例の統計的䆏察。臨外 $30: 498-506,1975$

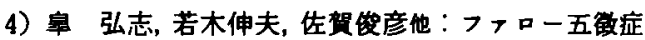
を伴った Morgagni 孔へルニフの1治跧例. 近畿 大医誌 8:139-148, 1983

5）村山祐一郎, 神吉 軎, 中村昭光 他：Moragagni 孔ヘルニフの 1 治会例之本邦報告例の检討. 胸部 外科 $35: 751-758,1982$

6）柄松章司，伊藤宽，城内 格他：Morgagni 孔一

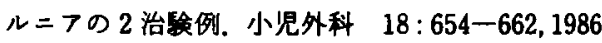

7）福地晋治，高梨吉則。石原茂樹他：新生児 Morgagni ヘルニフの治伢例．日小児外会誌 $21: 678$ $-684,1985$

8）宮埼五郎, 藤岡健二郎, 土屋度信他：傍胸骨横隔一 ルニフの1例および本邦赧告例の統計的瀵察. 胸 部外科 $12: 669-672,1959$

9）片山義民，赤木茂樹，阿多雄一他：モルガ二一裂孔 ヘルニアの1 例. 厷島医 $28: 908,1975$ 


\title{
A CASE OF MORGAGNI'S DIAPHRAGMATIC HERNIA COMPLICATED WITH AN EARLY CANCER IN THE STOMACH
}

\author{
Taiichiro KANAGAWA, Kunio OKAJIMA, Hitoshi MIZUTANI, Shnichi YAMADA, \\ Takatsugu ISHIBASHI and Akihiro NAKAMURA \\ Department of General Abdominal Surgery, Osaka Medical College \\ Toru KAWAI \\ Ootori-Icho Hospital
}

\begin{abstract}
A 76-year-old woman was referred to the hospital because of nausea. Plain X-ray films of the chest and abdomen showed a marked pool of gas and fluid level in the right thoracic cavity and left subdiaphragmatic region. Gastrointestinal radiography disclosed the prolapse of the gastric antrum and the transverse colon into the right thoracic cavity via the right parasternal hiatus-signs suggestive of Morgagni's diaphragmatic hernia. Gastrofluoroscopy revealed an irregular-shaped ulceration of the pyrolic region. Endoscopically this lesion was definitely diagnosed as poorly differentiated adenocarcinoma. Operation was performed by abdominal approach. The herniated organs were returned into the abdominal cavity via the Morgagni's foramen, and hiatus was closed. Subsequently extended gastrectomy and lymph node dissection were performed.

In our search for the literature, a total of 231 cases of Morgagni's diaphragmatic hernia were reported up to 1990 in Japan. As for Morgagni's diaphragmatic hernia complicated with malignant tumor, only two cases have been reported so far. However the present case of Morgagni's diaphragmatic hernia complicated with cancer in the herniated stomach is the first case of its kind. The case presented here suggests the possibility of complication with malignant tumor of the herniated organs in the treatment of Morgagni's diaphragmatic hernia in adults.
\end{abstract}

